\title{
Survey sampling for fisheries monitoring in Brazil: implementation and analysis
}

\author{
Laura Villwock de Miranda, ${ }^{1,5 *}$, Paul Gerhard Kinas ${ }^{1,2}$, Guilherme Guimarães Moreira ${ }^{3 \#, ~ R a f a e l ~}$ \\ Cabrera Namora ${ }^{4}$, Marcus Henrique Carneiro ${ }^{5}$
}

\author{
${ }^{1}$ Programa de Pós-Graduação em Oceanografia Biológica, Universidade Federal do Rio Grande (FURG). \\ (Av. Itália, km 8, Carreiros, 96203-900, Rio Grande, RS, Brazil). \\ ${ }^{2}$ Instituto de Matemática, Estatística e Física (IMEF/FURG). \\ (Av. Itália, km 8, Carreiros, 96203-900, Rio Grande, RS, Brazil). \\ ${ }^{3}$ Instituto Brasileiro de Geografia e Estatística (IBGE). \\ (Rua Oliveira, 523, $4^{\text {th }}$ floor, Cruzeiro, 31310-150, Belo Horizonte, MG, Brazil). \\ ${ }^{4}$ Fundação de Desenvolvimento da Pesquisa do Agronegócio (FUNDEPAG) \\ (Rua Dona Germaine Burchard, 409, Água Branca, 05002-062, São Paulo, SP, Brazil). \\ ${ }^{5}$ Instituto de Pesca de São Paulo (IP/APTA-SP) \\ (Rua Joaquim Lauro de Monte Claro Neto, 2275, Itaguá, 11680-000, Ubatuba, SP, Brazil).
}

*Corresponding author: lauravillwockmiranda@gmail.com

\section{Abstract}

Census of fishing data about the landings carried out along the São Paulo coast during 2011 was used to evaluate and compare the survey sampling for fisheries monitoring, expecting reliable results along with an important cost reduction. Estimates of total catch for the São Paulo State as a whole and by municipality were relatively accurate (high precision and low bias). Estimated catch by month, by fish categories and both (factors not considered in the sampling design) demonstrated that, as the level of required detail increased, the catch estimates became more biased and less precise. However, when comparing to the 2011 true catches, the order of importance of fish categories based on estimated catches changed slightly in some positions after the fifth place. There was a minor cost reduction due to the sampling in comparison with the census methodology currently in use $(15.4 \%$ at most). The results demonstrated that fisheries monitoring costs are directly proportional to the required level of details and data quality.

Descriptors: Fishing activity, Fishing landings, Sampling design, Inference, Monitoring costs.

\section{RESUMO}

Informações sobre as descargas pesqueiras realizadas em 2011 ao longo da costa de São Paulo foram utilizadas com o objetivo de avaliar e comparar os métodos de amostragem em campanhas voltadas para o monitoramento pesqueiro. Espera-se com isto um conjunto de dados consistentes, além de uma importante redução de custos. As estimativas da captura total para o estado de São Paulo e por municípios foram relativamente acuradas (alta precisão e baixo viés). A captura estimada por mês, por categoria de pescado e por ambos (domínios não considerados no desenho amostral) demonstraram que quanto maior é o nível de detalhamento menos precisas e mais enviesadas tornam-se as estimativas de captura. Quando comparada com as capturas reais para 2011, a ordem de importância das categorias de pescado baseada nas capturas estimadas alterou-se ligeiramente em algumas posições após o quinto lugar. Houve uma pequena redução de custos devido à amostragem em comparação com a metodologia censitária atualmente em uso no estado de São Paulo (máxima de $15,4 \%$ ). Os resultados demonstraram que os custos do monitoramento pesqueiro são diretamente proporcionais ao nível de detalhamento e à qualidade dos dados requeridos.

Descritores: Atividade pesqueira, Descargas pesqueiras, Desenho amostral, Inferência, Custos de monitoramento.

\footnotetext{
\# IBGE is exempt from any responsibility for the opinions, information, data and concepts presented in this report which are exclusive responsibility of the authors.
} 


\section{INTRODUCTION}

Catch and fishing effort are the most basic information that can be obtained about any fishing activity. To guarantee that at least these data are reliably collected and maintained over time is crucial to formulate effective fisheries policies and management plans (HILBORN; WALTERS, 1992; CADIMA, 2003).

Monitoring and obtaining fishing information can be performed in two forms: by sampling surveys (CADDY; BAZIGOS, 1985; ARAGÃO; MARTINS, 2006; LIMAGREEN; MOREIRA, 2012) or by census (FAO, 1999; MENDONÇA; MIRANDA, 2008; ÁVILA-DA-SILVA et al., 2015). In general, a census is recommended when the population is small, sampling errors are large, information is cheap to obtain or the cost in making the wrong decisions is high. Sampling techniques must be used when the population is very large and/or the cost (concerning money and time) to obtain information is high (CADDY; BAZIGOS, 1985; BOLFARINE; BUSSAB, 2005).

When the available data constitute only a portion of a population (collected by sampling), then there are two ways of dealing with the inferences: (1) based on a sampling plan specially designed by a finite population with a controlled random selection procedure where all probabilities involved can be known (design-based); and (2) based on observational research (model-based), where there is no control over the sampling plan and the specification of a model plays a fundamental role to connect the observed data to the parameters of the population (COCHRAN, 1977; BUSSAB; MORETTIN, 2012). Basically, in a model-based approach, data are assumed to have been generated from a random process specified by a probability model so that conclusions can be generalized to other situations where the same process operates, while design-based inference cannot be generalized to other populations which were not sampled (LUMLEY, 2010).

The design-based approach is usually applied to the analysis of complex survey samples and, up to now, widely adopted by fisheries monitoring methodologies (FAO, 1999). Estimates of total catch, their variance and any other population quantities are obtained based on the Horvitz-Thompson estimator (HORVITZ; THOMPSON, 1952). This is an unbiased estimator of population total applicable to any sampling design with or without replacement, from a finite population, when unequal but known selection probabilities are used. The estimation procedure weighs each selected unit by the inverse of its overall selection probability and known nonzero pairwise probabilities are required for unbiased variance estimation (LUMLEY, 2010).

Historically, fisheries monitoring in Brazil has certainly been influenced by different political and institutional arrangements made along the development of national extractive fishery (DIAS-NETO, 2010, 2011; LIMA-GREEN; MOREIRA, 2012). The adoption of different methodologies for different fisheries or for the same fishery in time has been common, with periods of interruption in data collection in different regions along the Brazilian coast.

In some States of Brazil, the EstatPesca (ARAGÃO; MARTINS, 2006) was the most adopted sampling methodology for fisheries monitoring since the nineties (LIMA-GREEN; MOREIRA, 2012). This methodology was based on the follow-up of fixed samples of fishing vessels, which required a permanently updated registry of all vessels in operation. This proved impracticable, mainly for small-scale fisheries, where sales and changes in the names and in the characteristics of the vessels are very frequent. It was also usual that vessel sampling was intentionally motivated by logistics considerations and not conducted as a probabilistic sampling survey and, therefore, subjected to bias (ISAAC et al., 2008). In order to reduce biased estimates, more samples should be taken, increasing the costs of the sampling process. ISAAC et al. (2008) observed a catch overestimation when EstatPesca was applied to the fisheries monitoring of the Pará State (Northern Brazil) and concluded that at least $70 \%$ of the fleet should be sampled to place the error of the estimates at acceptable levels.

A new sampling methodology for fisheries monitoring has been proposed by LIMA-GREEN and MOREIRA (2012), technicians from the official Brazilian Institute of Statistics, the "Instituto Brasileiro de Geografia e Estatística" (IBGE). This methodology aimed to avoid the weakness detected in EstatPesca by defining fishing landings as sample unit instead of fishing vessels. Its use has been gaining recognition in Brazil, since the government has been supporting and encouraging its adoption for new programs for fisheries monitoring. However, this is a sampling design method that can present some limitations for use in survey sampling of fishing activity, by its great diversity, variable characteristics and different strategies. The use of different combinations of more than one fishing gear on a same trip, several fishing seasons and many 
target species, besides fishing landings with small catches spread over large extensions of the coast are some of the characteristics described for small-scale fishing in Brazil (ISAAC et al., 2000, 2008; MENDONÇA; MIRANDA, 2008). Furthermore, when the IBGE methodology is applied with a two stages sampling, the total numbers of landings carried out in a fishing lading place must be known. This information can be very difficult to be obtained and, of course, it is not known in advance. Many factors can influence the dynamics of fishing landings, such as the size of the landing facility, the number of fishing vessels and fishermen at this facility, the fishing seasons, the type of fishing fleet and the fishing gears used by this fleet.

Fisheries monitoring of the São Paulo coast is, however, an exception in Brazil and its first records of fishing information dates back to 1944 . Since its creation in 1969, the Fisheries Institute of the Department of Agriculture and Food Supply of São Paulo State has been the institution responsible for the collection, storage, processing and disclosure of census data (FAO, 1999) about the marine fisheries production landed along the São Paulo coast (MENDONÇA; MIRANDA, 2008; ÁVILADA-SILVA et al., 2015).

Realistic and good quality data, where the true total population is known, are required to evaluate and compare survey sampling methods (LUMLEY, 2010). In this paper, the complete fishing data of São Paulo State collected during 2011 were used to simulate probability samples following the sampling design described by LIMA-GREEN and MOREIRA (2012) and to compare the results of these simulations to the true total landed catches. In addition to the quality of estimates, the costs to perform fisheries monitoring on the São Paulo coast were also considered in order to evaluate losses and gains of the sampling methodology when compared to census data collection. The hypothesis of this study is that the survey sampling method applied to fisheries monitoring of the São Paulo coast will generate reliable results along with an important cost reduction when compared to the census data collection.

\section{MATERIAL AND METHODS}

\section{OBTAINING FISHING INFORMATION}

Fishing landings census data collected on the São Paulo coast during 2011 were used to apply the sampling methodology for fisheries monitoring proposed by
IBGE (LIMA-GREEN; MOREIRA, 2012). These data were obtained through the Fishing Activity Monitoring Program (PMAP), coordinated by fisheries scientists from the Fisheries Institute of the Department of Agriculture and Food Supply of São Paulo State.

In March 2008, PMAP began to be used aiming to evaluate the impact on fishing activity by oil and gas exploration activities by Petrobras in the Santos Basin. The PMAP applies the census methodology to collect fisheries statistics (FAO, 1999; MENDONÇA; MIRANDA, 2008; ÁVILA-DA-SILVA et al., 2015), and currently monitors 196 fishing ports and landing places (just "ports" in the remaining text) in 15 municipalities included in the area of influence of the oil and gas exploration in Santos Basin. The municipality of Santos has only one port and was considered a single municipality together with the neighboring city of Guarujá to preserve the confidentiality of information. In order to obtain information on catch and fishing effort, field agents perform structured interviews with fishermen on the occasion of landing. This information is complemented with retrieved fishermen's records about their daily fishing operations (self-registration), in logbooks and with records provided by fishing enterprises. The storage, processing, analysis and provision of fishery statistics are carried out by the System Manager ProPesq ${ }^{\circledR}$ (ÁVILA-DA-SILVA et al., 1999), currently operating in a web platform, called ProPesqWEB (http://www.propesq. pesca.sp.gov.br).

\section{APPLYING SAMPLING METHODOLOGY TO FISHER-} IES MONITORING

The organization and structuring of fishing landings census data of the State of São Paulo and the sampling design to extract fishing landings from it were defined during a Workshop with technicians of IBGE, who are the authors of the methodology being validated (LIMAGREEN; MOREIRA, 2012).

\section{THE REGISTRY OF PORTS}

Information about all reported fishing landings (just "landings" in the remaining text) carried out on São Paulo coast during 2011 was extracted from the database of the Fisheries Institute, comprising 227 ports, although some of them with very few landings or located too close to one another. In order to define the population of interest and conclude this register, the following criteria were adopted: (1) Remove the ports with fewer than 40 landings per year 
(fewer than one weekly landing); (2) Reconsider all ports with at least one landing greater than $500 \mathrm{t}$; (3) Gather in a single port all places which, for logistics, have distinct names in the database, but in practice could be part of only one port; (4) Remove from the registry, the ports that were deactivated in 2013. After accomplishing these steps, the register was finalized with a total of 133 ports located along the entire coast of Sao Paulo State (Figure 1).

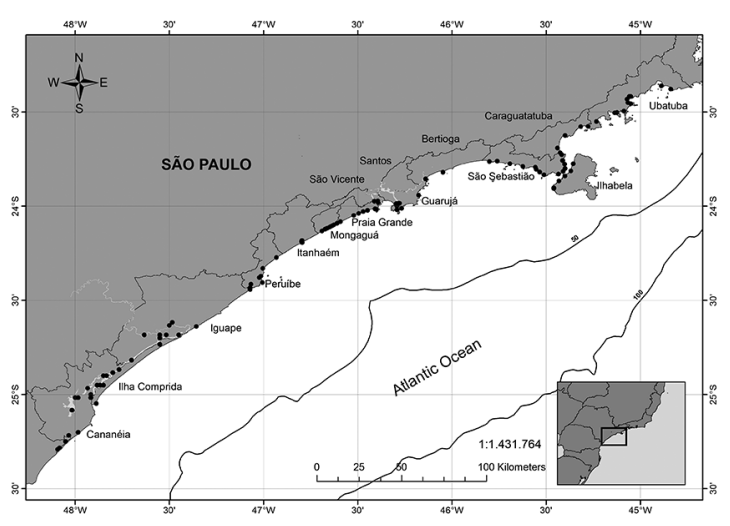

Figure 1: Location of fishing ports and landing places monitored in 2011 on the coast of São Paulo, Brazil included in the register (population of interest) for the analysis.

\section{SAMPLING DESIGN BASED ON CATCH INFORMATION}

The IBGE methodology is based on a complex sampling design, composed of stratification of the ports and conglomeration of landings within ports for the calculation of total catch estimates and their associated sampling errors or coefficients of variation. This study assumed a single conglomerate sampling design, i.e., the information of all landings carried out at sampled ports was considered in the analysis.

According to LIMA-GREEN and MOREIRA (2012), the ports should be previously divided into strata regarding their importance. One stratum called census stratum was composed of ports selected arbitrarily by their importance, according to historical total landed catches. For all others, called sampled strata, simple random samples (without replacement) of ports were used.

Experts from the Fisheries Institute of São Paulo made the stratification of ports for each municipality into strata. The rules for stratification were: (1) to separate a maximum of three ports into census stratum; (2) to subdivide the remaining ports into as many strata as deemed necessary to achieve approximate homogeneous landings (i.e. small, medium or large); and (3) each sampled stratum should be composed of at least three ports. The municipalities of Itanhaém, São Vicente and Bertioga have three or fewer ports and therefore all of them comprised the census stratum. Any port with unmatched specificity in landings, when identified, was transferred to the census stratum because it could cause distortions in later sample expansion.

\section{EXPANSION AND STATISTICAL INFERENCE}

All estimates of this study were obtained through software R (R CORE TEAM, 2015) using package Sampling (TILLÉ; MATEI, 2015) for the port sampling and package Survey (LUMLEY, 2014) for the estimate calculations. The sample sizes were defined to be two ports, randomly chosen, in strata with up to six ports and three ports for all others. Therefore, a total of 77 ports composed the sample, 36 in the census strata and 41 in the sampled strata. Main equations used in this analysis are specified in Table 1.

This study performed 100 simulations, each containing the sample selection of ports and total catch estimation for each one of the 14 municipalities of São Paulo. For each of the 100 simulations, the estimated total landed catch by municipality $\left(\widehat{Y}_{i}^{(k)}-\right.$ Equation 10) and associated standard error $\left(S E_{i}^{(k)}-\right.$ Equation 3$)$, the coefficient of variation $\left(C V_{i}^{(k)}-\right.$ Equation 4), the square root of the mean squared error $\left(R M S E_{i}^{(k)}-\right.$ Equation 17), the percentage bias (\% $B_{i}^{(k)}$ - Equation 5) with respect to the true total landed catch of 2011 ( $Y_{i}-$ Equation 7), and the design effect (Deff $f_{i}^{(k)}$ - Equation 18) were calculated. Furthermore, the annual economic cost of fisheries monitoring, obtained as a sum of costs for sampled ports, was also obtained in each simulation. The R package Survey (LUMLEY, 2014) estimates standard errors (SE) as the square root of the Horwitz-Thompson estimated variance of the total population, and was implemented with the option 'ultimate cluster' method (Equation 13). The best sample allocation of ports within each municipality was chosen from the 100 simulations under two criteria: Sampling Plan 1 (SP1) the sample with the lowest RMSE; Sampling Plan 2 (SP2) - the sample with the lowest economic cost. It is important to clarify that whenever referring to accuracy or to an accurate estimate in the remaining text, the compromise between the variance and the squared bias of the estimate will be considered (low RMSE).

The final estimate of the total catch by municipality $\left(\widehat{\bar{Y}}_{i}^{(k)}-\right.$ Equation 19) was obtained by a simple average of the 100 simulated estimates and the coefficient of variation $\left(C V_{i}\right)$ was calculated from its standard error 
Table 1. Main equations used to obtain estimated total catch and its measures of variability and bias by municipalities and total of São Paulo State. A - Symbology; $i$ - Municipality; $p$ - Port; $h$ - Stratum; $H_{i}$ - Total number of sampled strata in municipality $i$; $M_{i h}$ - Total number of ports in sampled stratum $h$ and municipality $i ; m_{i h}$ - Total number of sampled ports in sampled stratum $h$ and municipality $i ; k$-Simulation; $Y$ - True total landed catch; $\widehat{Y}$ - Estimated total landed catch.

\begin{tabular}{|c|c|c|}
\hline General equations & & Description \\
\hline Eq. 1 & $\widehat{T}_{\mathrm{x}}=\sum_{a=1}^{n} \frac{1}{\pi_{a}} X_{a} \quad$ where $\pi_{a}=\frac{m}{M}$ & $\begin{array}{l}\text { Horvitz-Thompson estimator } \widehat{T}_{\mathrm{x}} \text { for the population total } T_{X} \text { of the } \\
\text { variable } \mathrm{X} \text {, based on a sample of size } n \text {, with } \pi_{a} \text { probability that a } \\
\text { particular unit is sampled. }\end{array}$ \\
\hline Eq. 2 & $\widehat{V}\left(\widehat{T}_{\mathrm{x}}\right)=\sum_{a, b}\left(\frac{X_{a} X_{b}}{\pi_{a, b}}-\frac{X_{a}}{\pi_{a}} * \frac{X_{b}}{\pi_{b}}\right)$ & $\begin{array}{l}\text { Variance estimate of Horvitz-Thompson estimator } \widehat{T}_{\mathrm{x}} \text { where } \pi_{a} \\
\text { is the probability that unit } a \text { is sampled and } \pi_{a, b} \text { is the pairwise } \\
\text { sampling probability that both units, } a \text { and } b \text {, are sampled. }\end{array}$ \\
\hline Eq. 3 & $\widehat{S E}\left(\widehat{T}_{\mathrm{x}}\right)=\sqrt{\widehat{\operatorname{var}}\left(\widehat{T}_{\mathrm{x}}\right)}$ & Standard Error \\
\hline Eq. 4 & $\widehat{C V}\left(\widehat{T}_{\mathrm{x}}\right)=\frac{\widehat{S E}\left(\widehat{T}_{\mathrm{x}}\right)}{\widehat{T}_{\mathrm{x}}} * 100$ & Coefficient of Variation \\
\hline Eq. 5 & $\% B=\left(\frac{\widehat{T}_{\mathrm{x}}-T_{\mathrm{x}}}{T_{\mathrm{x}}}\right) * 100$ & Bias expressed as percentage of true total landed catch. \\
\hline Specific Equations & & Description \\
\hline \multicolumn{3}{|c|}{ True values of total landed catch } \\
\hline Eq. 6 & $Y_{i h}=\sum_{p=1}^{M_{i h}}$ & $\begin{array}{l}\text { True total landed catch in sampled stratum } h \text { and municipality } i \text {, } \\
\text { where } Y_{i h p} \text { is the true total landed catch of each port for the stratum } \\
\text { and municipality. }\end{array}$ \\
\hline Eq. 7 & $Y_{i}=\sum_{h=1}^{H_{i}} Y_{i h}$ & True total landed catch for municipality $i$. \\
\hline Eq. 8 & $Y_{S P}=\sum_{p=1}^{14} Y_{i}$ & True total landed catch for São Paulo State as a whole. \\
\hline Specific Equations & & Description \\
\hline \multicolumn{3}{|c|}{ Estimates for each simulation $(\mathrm{k})$} \\
\hline \multicolumn{3}{|c|}{ Estimated values of total catch } \\
\hline Eq. 9 & $\widehat{Y}_{i h}^{(k)}=\sum_{p=1}^{m_{i h}} \frac{M_{i h}}{m_{i h}} Y_{i h p}^{(k)}$ & $\begin{array}{l}\text { Estimated total landed catch in sampled stratum } h \text { and municipality } \\
i, \text { where the sum is over the sampled ports within }(i, h) .\end{array}$ \\
\hline Eq. 10 & $\widehat{Y}_{i}^{(k)}=\sum_{h=1}^{H_{i}} \widehat{Y}_{i h}^{(k)}$ & Estimated total landed catch for municipality $i$. \\
\hline Eq. 11 & $\widehat{Y}_{S P}^{(k)}=\sum_{i=1}^{14} \widehat{Y}_{i}^{(k)}$ & Estimated total landed catch for São Paulo State as a whole. \\
\hline \multicolumn{3}{|l|}{ Estimated Variances } \\
\hline Eq. 12 & $\widehat{\bar{Y}}_{i h}^{(k)}=\frac{\sum_{p=1}^{M_{i h}} \widehat{Y}_{i h}^{(k)}}{M_{i h}}$ & $\begin{array}{l}\text { Mean of estimated total landed catch in sampled stratum } h \text { and } \\
\text { municipality } i \text {. }\end{array}$ \\
\hline Eq. 13 & $\widehat{V}\left(\widehat{Y}_{i h}^{(k)}\right)=\sum_{h=1}^{H_{i}}\left[\frac{m_{i h}}{1-m_{i h}} \sum_{p=1}^{m_{\text {in }}}\left(Y_{i h p}{ }^{(k)}-\widehat{\bar{Y}}_{i h p}{ }^{(k)}\right)^{2}\right]$ & $\begin{array}{l}\text { Simplified and conservative estimated variance of the estimates in } \\
\text { sampled stratum } h \text { and municipality } i \text { obtained through the Ultimate } \\
\text { cluster method. }\end{array}$ \\
\hline Eq. 14 & $\widehat{V}\left(\widehat{Y}_{i}^{(k)}\right)=\sum_{h=1}^{H_{i}} \widehat{V}\left(\widehat{Y}_{i h}^{(k)}\right)$ & Estimated variance of the estimates for municipality $i$. \\
\hline
\end{tabular}


Eq. $15 \quad \widehat{V}\left(\widehat{Y}_{S P}^{(k)}\right)=\sum_{i=1}^{14} \widehat{V}\left(\widehat{Y}_{i}^{(k)}\right) \quad$ Estimated variance of the estimates for São Paulo State as a whole.

Other definitions

Eq. $16 \quad B_{i}^{(k)}=\left(\widehat{Y}_{i}^{(k)}-Y_{i}\right)$

Bias of the estimates for municipality $i$.

Eq. 17

$R M S E_{i}^{(k)}=\sqrt{\widehat{V}\left(\widehat{Y}_{i}^{(k)}\right)+\left(B_{i}^{(k)}\right)^{2}}$

Squared root of the mean squared error of the estimates for municipality $i$.

Eq. $18 \quad \operatorname{Deff}_{i}^{(k)}=\frac{\widehat{V}\left(\widehat{Y}_{i}^{(k)}\right)}{\widehat{V}_{s r s}\left(\widehat{Y}_{i}^{(k)}\right)}$

Design Effect of the estimates for municipality $i$, where $\widehat{V}_{s r s}\left(\widehat{Y}_{i}^{(k)}\right)$ is the estimated variance of a simple random sample of landings of the same size.

Estimates with all 100 simulations

Eq. $19 \quad \widehat{\bar{Y}}=\frac{\sum_{k=1}^{100} \widehat{Y}_{i}^{(k)}}{100}$

Mean of estimated total landed catch obtained as a simple average of 100 simulated estimates of the total catch for municipality $i$.

Eq. 20

$\widehat{V}(\widehat{\bar{Y}})=\frac{\sum_{k=1}^{100}\left(\widehat{Y}_{i}^{(k)}-\widehat{\bar{Y}}\right)^{2}}{100-1}$

Variance of the mean of estimated total landed catch of 100

simulations for municipality $i$.

( $\mathrm{SE}_{\mathrm{i}}$ - Square root of $\widehat{V}\left(\widehat{\bar{Y}}_{i}\right)-$ Equation 20). The coverage of the confidence interval $(1-\alpha=0.95)$ (CI95) was obtained by counting the samples (simulations) for which the true landed catch $\left(Y_{i}\right)$ was encompassed by the CI95.

\section{OBTAINING FISHERIES MONITORING COSTS}

Information gathered by the PMAP was used to obtain: the cost for monitoring each port, the total cost for each sample by adding over the costs of its set of ports and also to select the best sample according to SP2.

In PMAP, distant ports are monitored through regular field trips using institutional or private vehicles. Although the combination of ports monitored per trip can vary for different reasons, to simplify, the cost calculation assumed individual trips to each port. The cost of fuel (in liters/ month) per port was obtained based on the distance traveled (round trip), weekly frequency of monitoring and fuel consumption $(1 / \mathrm{km})$ in accordance with the type of vehicle (car, motorcycle or boat). Other costs include wages, equipment, supply and maintenance, food and lodging and services like database and computers maintenance, printing and telephony and were all used to obtain the cost of each employee.

Depending on the number and set of ports to be monitored, the number of monitors (supervisors), field agents and typists varies. Aiming at a lower cost, the number of field agents in SP2, compared to SP1, was reduced. The number of typists was based on the total number of hours required to include all landings from the set of sampled ports, which considered the number of reported landings and the ability to include 20 landings per hour into the database. Typing cost by port considered the inclusion cost by landing into the database (total cost with typists divided by the total number of landings times the number of landing per port). The total cost of each remaining employee was divided by the attended ports under his/her responsibility. Expenses related to the coordination and management of the PMAP, despite being overhead costs, were also considered and equally divided between ports that comprised each sampled set. The calculations were based on the highest wage for each position and did not include the administration fees.

\section{RESULTS}

The estimated total catch per municipality was obtained together with the associated coefficient of variation, percentage bias and CI95 coverage (Table 2). For municipalities with few ports (Bertioga, Itanhaém and São Vicente), all ports were allocated in the census stratum and the dispersion measures were therefore equal to zero. Estimates of the total landed catch in all remaining municipalities had low bias, but the maximum $\mathrm{CV}$ among samples was obtained in Caraguatatuba (12.0\%). The coverage of the CI95 has not encompassed the true value of catches in $95 \%$ of samples as it should, except for Ilha Comprida where the coverage was complete $(100 \%)$.

For each municipality, among the 100 sets of sampled ports, the set resulting in the smallest RMSE (SP1) 
was chosen (Table 3). The estimates with the highest variability $(\mathrm{CV})$ were obtained in the municipalities of Caraguatatuba, Iguape, Ilha Comprida, Mongaguá, Praia Grande and São Sebastião, which also presented values of design effect (Deff) greater than one, indicating that the stratification made between ports for these municipalities did not improve in comparison to simple random sampling. Caraguatatuba had estimates with the highest values of $\mathrm{CV}$ and bias. The best results were found for Ubatuba.

In Table 4, similar inference results are shown for the selected set of ports for each municipality providing the lowest monitoring cost (SP2). Catch estimates were less accurate than those found for SP1, which is demonstrated by the higher CV value and RMSE for virtually all municipalities (except for Caraguatatuba and Ilha Comprida that had equal values).

The results that will be presented from now on, and in more detail, refer only to the set of ports by municipality resulting in the smallest RMSE (SP1). After obtaining the estimates of total catch per municipality, some other domain estimations (month and fish categories) that were not considered in the sampling design, were made.

Monthly catch estimates for São Paulo State as a whole and associated dispersion measures are displayed in Table 5. Despite the relatively accurate estimates, the worst results were observed in February (largest CV) and November (largest bias).
Fish categories landed on the São Paulo coast over 2011 (identified at minor taxonomic rank possible during data collection) were also considered as domain to compute the catch estimates (Table 6). The 20 most important fish categories (in relation to landed catch) have been listed. All remaining categories have been lumped together in "Others". Incidental landed catches have also been included in the analysis. Considering $\mathrm{CV}$ and bias, Crassostrea brasiliana and Opisthonema oglinum were the species with the worst and the best estimates of catch, respectively. In relation to the estimated number of trips, C. brasiliana had the worst estimates again while Menticirrhus spp had the best results. The CV of estimated number of trips by fish category tended to be greater than the CV of estimated catch. With this information, the estimated LPUE (reported Landed catch Per Unit of Effort, $\mathrm{kg}^{*}$ trip $^{-1}$ ) calculated for 2011 was compared to the true LPUE and few differences were observed (Table 6). When comparing estimated and actual catches for 2011, it was found that the order of importance of fish categories in landings of São Paulo has remained the same for the first four categories and showed a slight difference in some of the remaining positions (Figure 2). Only Macrodon atricauda, Octopus vulgaris, Mugil liza and Doryteuthis spp were ranked worse than actual order by two or more positions while $C$. brasiliana was the only category really badly ranked, with eight positions higher than actual order.

Table 2. Results obtained by simple average between 100 estimates of the total catch (tons) by municipality for São Paulo coast over 2011. $Y_{i}$ - True total landed catch (tons); $\widehat{\bar{Y}_{i}}-$ Estimates of total landed catch (tons); $C V_{i}$ - Coefficient of variation between averages; $\% B_{i}$ - Bias expressed as percentage of catch 2011.

\begin{tabular}{|c|c|c|c|c|c|}
\hline Municipality & $Y_{i}$ & $\widehat{\overline{Y_{i}}}$ & $C V_{i}$ & $\% B_{i}$ & Coverage CI95 \\
\hline Bertioga & 216.13 & 216.13 & 0.00 & 0.00 & \\
\hline Cananéia & 3289.96 & 3274.14 & 3.85 & -0.48 & 81 \\
\hline Caraguatatuba & 139.58 & 139.54 & 12.01 & -0.03 & 68 \\
\hline Iguape & 1078.18 & 1064.39 & 6.98 & -1.28 & 77 \\
\hline Ilha Comprida & 56.97 & 56.60 & 4.89 & -0.65 & 100 \\
\hline Ilhabela & 702.15 & 703.85 & 2.19 & 0.24 & 56 \\
\hline Itanhaém & 45.47 & 45.47 & 0.00 & 0.00 & \\
\hline Mongaguá & 53.94 & 53.88 & 4.96 & -0.10 & 67 \\
\hline Peruíbe & 147.66 & 147.44 & 3.26 & -0.15 & 66 \\
\hline Praia Grande & 81.00 & 80.37 & 6.04 & -0.78 & 86 \\
\hline Santos/Guarujá & 11423.33 & 11500.55 & 5.43 & 0.68 & 90 \\
\hline São Sebastião & 556.93 & 554.27 & 9.20 & -0.48 & 71 \\
\hline São Vicente & 105.93 & 105.93 & 0.00 & 0.00 & \\
\hline Ubatuba & 2064.56 & 2066.23 & 0.98 & 0.08 & 81 \\
\hline São Paulo State & 19961.80 & 20008.79 & 3.22 & 0.24 & \\
\hline
\end{tabular}


Table 3: Results of the Sampling Plan 1 (SP1) - the lowest square root of the mean squared error (RMSE) - by municipality for São Paulo coast over 2011. $Y_{i}$ - True total landed catch (tons); $\widehat{Y}_{i}^{(k)}$ - Estimates of total landed catch (tons); $C V_{i}^{(k)}$ - coefficient of variation within each municipality; $\% B_{i}^{(k)}$ - Bias expressed as percentage of catch 2011; Deff ${ }_{i}^{(\mathrm{k})}$ - design effect; Annual cost in December 2015 - rounded and expressed in USD (R\$ 3.70 in Brazilian currency).

\begin{tabular}{lccccccc}
\hline Municipality & $Y_{i}^{(k)}$ & $\widehat{\bar{Y}}_{i}^{(k)}$ & $C V_{i}^{(k)}$ & $\% B_{i}^{(k)}$ & RMSE $E_{i}^{(k)}$ & Deffi & Annual Cost \\
\hline Bertioga & 216.13 & 216.13 & 0.00 & 0.00 & 0.00 & 0.00 & 31200.00 \\
Cananéia & 3289.96 & 3287.71 & 1.82 & -0.07 & 59.88 & 0.33 & 120050.00 \\
Caraguatatuba & 139.58 & 156.52 & 11.14 & 12.13 & 24.31 & 104.88 & 53675.00 \\
Iguape & 1078.18 & 1112.83 & 1.57 & 3.21 & 38.80 & 3.71 & 115820.00 \\
Ilha Comprida & 56.97 & 60.29 & 3.27 & 5.83 & 3.86 & 24.41 & 53195.00 \\
Ilhabela & 702.15 & 702.01 & 1.49 & -0.02 & 10.44 & 0.31 & 43975.00 \\
Itanhaém & 45.47 & 45.47 & 0.00 & 0.00 & 0.00 & 0.00 & 35340.00 \\
Mongaguá & 53.94 & 55.02 & 5.00 & 2.01 & 2.95 & 12.27 & 52215.00 \\
Peruíbe & 147.66 & 150.49 & 0.91 & 1.92 & 3.14 & 0.26 & 70830.00 \\
Praia Grande & 81.00 & 80.96 & 4.21 & -0.05 & 3.41 & 7.74 & 47340.00 \\
Santos/Guarujá & 11423.33 & 11186.90 & 3.60 & -2.07 & 467.13 & 0.21 & 113570.00 \\
São Sebastião & 556.93 & 535.32 & 5.23 & -3.88 & 35.38 & 2.48 & 120920.00 \\
São Vicente & 105.93 & 105.93 & 0.00 & 0.00 & 0.00 & 0.00 & 37695.00 \\
Ubatuba & 2064.56 & 2057.11 & 0.10 & -0.36 & 7.70 & 0.00 & 130010.00 \\
São Paulo State & 19961.80 & 19752.69 & 2.07 & -1.05 & 459.50 & 1025835.00 \\
\hline
\end{tabular}

Table 4. Results of the Sampling Plan 2 (SP2) - the lowest economic cost - by municipality for São Paulo coast over 2011. $Y_{i}$ - True total landed catch (tons); $\widehat{Y}_{i}^{(k)}$ - Estimates of total landed catch (tons); $C V_{i}^{(k)}$ - coefficient of variation within each municipality; $\% B_{i}^{(k)}$ - Bias expressed as percentage of catch 2011; Deff $f_{i}^{(k)}$ - design effect; Annual cost in December 2015 rounded and expressed in USD (R 3.70 in Brazilian currency).

\begin{tabular}{|c|c|c|c|c|c|c|c|}
\hline Municipality & $Y_{i}^{(k)}$ & $\widehat{\bar{Y}}_{i}^{(k)}$ & $C V_{i}^{(k)}$ & $\% B_{i}^{(k)}$ & $R M S E_{i}^{(k)}$ & $\operatorname{Deff}_{i}^{(k)}$ & Annual Cost \\
\hline Bertioga & 216.13 & 216.13 & 0.00 & 0.00 & 0.00 & 0.00 & 31335.00 \\
\hline Cananéia & 3289.96 & 3274.10 & 6.45 & -0.48 & 211.64 & 2.91 & 116720.00 \\
\hline Caraguatatuba & 139.58 & 116.02 & 5.13 & -16.89 & 24.31 & 23.77 & 49575.00 \\
\hline Iguape & 1078.18 & 1013.83 & 7.34 & -5.97 & 98.39 & 48.88 & 103820.00 \\
\hline Ilha Comprida & 56.97 & 60.29 & 3.27 & 5.83 & 3.86 & 24.41 & 46940.00 \\
\hline Ilhabela & 702.15 & 712.45 & 3.22 & 1.47 & 25.16 & 2.18 & 56750.00 \\
\hline Itanhaém & 45.47 & 45.47 & 0.00 & 0.00 & 0.00 & 0.00 & 35425.00 \\
\hline Mongaguá & 53.94 & 51.00 & 2.40 & -5.44 & 3.18 & 2.07 & 52205.00 \\
\hline Peruíbe & 147.66 & 142.92 & 4.01 & -3.22 & 7.44 & 6.96 & 71275.00 \\
\hline Santos/Guarujá & 11423.33 & 10953.47 & 4.06 & -4.11 & 646.91 & 0.14 & 97090.00 \\
\hline São Sebastião & 556.93 & 489.36 & 2.97 & -12.13 & 69.11 & 0.49 & 109510.00 \\
\hline São Vicente & 105.93 & 105.93 & 0.00 & 0.00 & 0.00 & 0.00 & 38000.00 \\
\hline Ubatuba & 2064.56 & 2043.50 & 0.51 & -1.02 & 23.51 & 0.01 & 121240.00 \\
\hline São Paulo State & 19961.80 & 19296.40 & 2.58 & -3.33 & 831.55 & & 977120.00 \\
\hline
\end{tabular}

To the extent that the level of detail increased, more biased and less precise the estimates have become. This can be seen in Table 7 where monthly estimated catches by fish categories over 2011 and the associated CV are shown.
With two domains being considered at the same time for catch estimates (month and fish categories), CV of some of these combinations were much greater than when only one of these domains was considered (Tables 5 and 6) as, 
Table 5. Results of the Sampling Plan 1 (SP1) - the lowest square root of the mean squared error (RMSE) - by month for São Paulo coast over 2011. Catches are expressed in tons; $C V$ - coefficient of variation within each month; $\% B-$ Bias expressed as percentage of catch 2011.

\begin{tabular}{|c|c|c|c|c|}
\hline Month & Catch 2011 & Estimated catch & $C V$ & $\% B$ \\
\hline January & 1216.95 & 1170.96 & 2.99 & -3.78 \\
\hline February & 1332.73 & 1355.35 & 5.69 & 1.70 \\
\hline March & 1208.75 & 1279.73 & 2.91 & 5.87 \\
\hline April & 1299.85 & 1390.45 & 2.53 & 6.97 \\
\hline May & 1217.87 & 1265.60 & 4.25 & 3.92 \\
\hline June & 1547.84 & 1498.77 & 1.88 & -3.17 \\
\hline July & 1300.29 & 1286.30 & 3.86 & -1.08 \\
\hline August & 2233.64 & 2194.97 & 2.18 & -1.73 \\
\hline September & 1830.74 & 1810.24 & 1.88 & -1.12 \\
\hline October & 3414.64 & 3379.20 & 1.74 & -1.04 \\
\hline November & 1700.62 & 1579.03 & 5.00 & -7.15 \\
\hline December & 1657.89 & 1542.09 & 3.43 & -6.98 \\
\hline Total & 19961.80 & 19752.69 & 2.07 & -1.05 \\
\hline
\end{tabular}

for example, observed for estimated catch of Cynoscion jamaicensis in May (Table 7). In Figure 3, monthly estimated catches for four of the 20 main fish categories landed in São Paulo State are presented, each displaying a different situation: estimates with some variability and bias (Micropogonias furnieri), estimates with relatively large bias (M. atricauda), accurate estimates (O. oglinum), and estimates with very large variability and bias $(C$. brasiliana).

In order to collect data from all 83137 landings carried out in 133 ports on the São Paulo coast over 2011 (census) 32 field agents, five monitors and four typists would be required. The scenarios SP1 (lowest RMSE) and SP2 (lowest fisheries monitoring cost) were compared to the census methodology and, in both, 77 ports were sampled, reducing the number of monitored ports by $42.1 \%$ compared to the census methodology. With this reduction, the same five monitors and three typists would be required. Considering only SP1, 27 field agents would be required since a $35.4 \%$ reduction in number of monitored landings were observed, decreasing the fisheries monitoring costs by $11.2 \%$. To monitor the ports of SP2, 24 field agents would be required with a $41.5 \%$ reduction in number of monitored landings and a $15.4 \%$ decrease in fisheries monitoring costs.

\section{DISCUSSION}

The fishing activity, especially the small-scale fishery, represents a seasonal, diversified and dynamic activity (CADIMA et al., 2005; ISAAC et al., 2008; MENDONÇA;
MIRANDA, 2008). These characteristics along with the need for accurate information lead to the adoption of complex survey plans for fisheries monitoring, such as the sampling methodology for fisheries monitoring proposed by IBGE (LIMA-GREEN; MOREIRA, 2012).

The accuracy of the total landed catch estimated through this methodology could only be judged because the true (population) values of landed catch in all municipalities of the São Paulo State are known. Therefore, a sampling distribution could be obtained by applying the same sampling procedure repeatedly (COCHRAN, 1977). The results demonstrated that the mean landed catch is a good estimator of the total landed catch for most municipalities since it was unbiased and had high precision. The low coverage of CI95 was attributed to the non-conformity of the Gaussian distribution used to build these intervals. The small number of possible sets of sampled ports (conglomerates) compromises the use of IC95 to evaluate the precision and the reliability of the estimates (BUSSAB; MORETTIN, 2012).

Comparing the results of each of the 100 simulated samples, it was clear that the set of sampled ports that provides the lowest RMSE is different from the set that provides the lowest monitoring cost. Hence, neither of the criteria for allocation of ports (SP1 and SP2) is optimum in the sense of COCHRAN (1977) sees it, in which the optimum allocation is achieved when, for a given sample size, the sample provides the most precision of the estimates at the lowest cost. Larger samples would increase costs while further reduction would leave some strata out 
Table 6. Results of the Sampling Plan 1 (SP1) - the lowest square root of the mean squared error (RMSE) - by fish category for São Paulo coast over 2011. Catches are expressed in tons; $C V$ - coefficient of variation within each fish category; \% $B-$ Bias expressed as percentage of catch 2011. Landed catch per unit of effort (LPUE) expressed in ton*trip ${ }^{-1}$.

\begin{tabular}{|c|c|c|c|c|c|c|c|c|c|c|}
\hline Minor taxonomic rank & $\begin{array}{c}\text { Catch } \\
2011\end{array}$ & $\begin{array}{c}\text { Estimated } \\
\text { catch }\end{array}$ & $C V$ & $\% B$ & $\begin{array}{c}\text { Number } \\
\text { of trips } \\
2011\end{array}$ & $\begin{array}{c}\text { Estimated } \\
\text { number of } \\
\text { trips }\end{array}$ & $C V$ & $\% B$ & $\begin{array}{c}\text { LPUE } \\
2011\end{array}$ & $\begin{array}{c}\text { Estimated } \\
L P U E\end{array}$ \\
\hline Sardinella brasilienses & 4105.09 & 4150.42 & 3.38 & 1.10 & 205 & 211 & 7.52 & 2.93 & 20.025 & 19.670 \\
\hline Xiphopenaeus kroyeri & 2759.11 & 2399.59 & 5.31 & -13.03 & 17618 & 14608 & 18.25 & -17.08 & 0.157 & 0.164 \\
\hline Micropogonias furnieri & 2102.17 & 2183.93 & 6.12 & 3.89 & 11311 & 10184 & 5.17 & -9.96 & 0.186 & 0.214 \\
\hline Cynoscion jamaicensis & 1036.34 & 1060.41 & 7.62 & 2.32 & 1003 & 1015 & 4.26 & 1.20 & 1.033 & 1.045 \\
\hline Macrodon atricauda & 705.18 & 634.20 & 2.15 & -10.07 & 8277 & 6136 & 7.74 & -25.87 & 0.085 & 0.103 \\
\hline Menticirrhus spp & 646.99 & 674.74 & 6.98 & 4.29 & 3357 & 3342 & 3.23 & -0.45 & 0.193 & 0.202 \\
\hline Anchoviella lepidentostole & 612.01 & 669.00 & 6.29 & 9.31 & 11630 & 11709 & 13.52 & 0.68 & 0.053 & 0.057 \\
\hline Selene spp & 480.40 & 482.36 & 2.44 & 0.41 & 849 & 759 & 19.24 & -10.60 & 0.566 & 0.636 \\
\hline Ariidae & 454.35 & 475.63 & 16.44 & 4.68 & 10835 & 10083 & 14.49 & -6.94 & 0.042 & 0.047 \\
\hline Octopus vulgaris & 355.26 & 316.69 & 3.66 & -10.85 & 722 & 668 & 4.22 & -7.48 & 0.492 & 0.474 \\
\hline Prionotus spp & 352.43 & 375.29 & 10.78 & 6.49 & 600 & 644 & 8.08 & 7.33 & 0.587 & 0.583 \\
\hline Opisthonema oglinum & 343.43 & 342.78 & 0.40 & -0.19 & 888 & 753 & 9.31 & -15.20 & 0.387 & 0.455 \\
\hline Mugil liza & 319.68 & 237.95 & 14.89 & -25.57 & 7053 & 6432 & 12.36 & -8.80 & 0.045 & 0.037 \\
\hline Oligoplites spp & 290.77 & 285.05 & 3.16 & -1.97 & 3110 & 2802 & 5.70 & -9.90 & 0.093 & 0.102 \\
\hline Doryteuthis spp & 256.73 & 208.11 & 4.34 & -18.94 & 2546 & 2422 & 3.46 & -4.87 & 0.101 & 0.086 \\
\hline Trichiurus lepturus & 255.64 & 271.10 & 9.03 & 6.05 & 3865 & 4144 & 6.01 & 7.22 & 0.066 & 0.065 \\
\hline Farfantepenaeus spp & 249.70 & 227.30 & 14.89 & -8.97 & 872 & 848 & 4.59 & -2.75 & 0.286 & 0.268 \\
\hline Urophycis spp & 193.85 & 217.03 & 13.63 & 11.96 & 259 & 267 & 6.62 & 3.09 & 0.748 & 0.813 \\
\hline Crassostrea brasiliana & 173.82 & 355.81 & 34.24 & 104.70 & 5354 & 10591 & 43.82 & 97.81 & 0.032 & 0.034 \\
\hline Caranx crysos & 170.84 & 158.05 & 5.39 & -7.48 & 744 & 787 & 24.76 & 5.78 & 0.230 & 0.201 \\
\hline Landed incidental catch * & 882.45 & 834.60 & 6.88 & -5.42 & 10661 & 8733 & 2.10 & -18.08 & 0.083 & 0.096 \\
\hline Others & 3215.56 & 3192.65 & 4.63 & -0.71 & 39721 & 37467 & 9.06 & -5.67 & 0.081 & 0.085 \\
\hline Total & 19961.80 & 19752.69 & 2.07 & -1.05 & 83137 & 80202 & 7.21 & -3.53 & 0.240 & 0.246 \\
\hline
\end{tabular}

* Fish of small size and/or low or no commercial value, however landed and marketed, composing the category called "Mistura" in fisheries statistics of the São Paulo State.

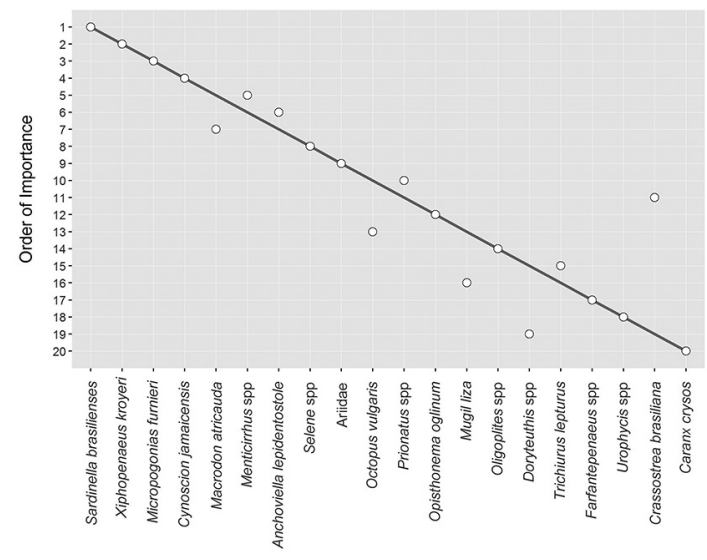

Figure 2. Order of importance in terms of catches of the 20 main species landed over 2011 on the São Paulo coast. Abscissa with true order for 2011 and ordinate with estimated order; matches between is a point on grey line. of the sample. Thus, since there is no marked difference in costs between SP1 and SP2, SP1 was chosen as the most appropriate allocation.

The common features of municipalities with the worst result (total landed catch estimates with low precision, large bias or high values of Deff) include few clustered ports within sampled strata with heterogeneous ports, as observed in Caraguatatuba and Ilha Comprida. To improve the precision of the estimated catch, the larger ports and possible outliers may be relocated from the sampled strata to census strata and/or larger samples must be taken, but both measures imply an increase in the monitoring costs. Applying this solution for Caraguatatuba and Ilha Comprida means having all their ports monitored, resulting in a lower reduction in the total fisheries monitoring cost 
Table 7. Results of the Sampling Plan 1 (SP1) - the lowest square root of the mean squared error (RMSE) - by month and fish category for São Paulo coast over 2011. Catches are expressed in tons; CV - coefficient of variation within each month and fish category.

\begin{tabular}{|c|c|c|c|c|c|c|c|c|c|c|c|c|}
\hline \multirow[t]{2}{*}{ Minor taxonomic rank } & \multicolumn{2}{|c|}{ January } & \multicolumn{2}{|c|}{ February } & \multicolumn{2}{|c|}{ March } & \multicolumn{2}{|c|}{ April } & \multicolumn{2}{|c|}{ May } & \multicolumn{2}{|c|}{ June } \\
\hline & $\begin{array}{c}\text { Est. } \\
\text { Catch }\end{array}$ & $C V$ & $\begin{array}{c}\text { Est. } \\
\text { Catch }\end{array}$ & $C V$ & $\begin{array}{c}\text { Est. } \\
\text { Catch }\end{array}$ & $C V$ & $\begin{array}{c}\text { Est. } \\
\text { Catch }\end{array}$ & $C V$ & $\begin{array}{c}\text { Est. } \\
\text { Catch }\end{array}$ & $C V$ & $\begin{array}{c}\text { Est. } \\
\text { Catch }\end{array}$ & $C V$ \\
\hline Sardinella brasilienses & 0.00 & 109.54 & 36.91 & 0.61 & 387.29 & 5.79 & 349.84 & 17.50 & 249.82 & 0.00 & 108.28 & 0.00 \\
\hline Xiphopenaeus kroyeri & 265.09 & 6.96 & 202.53 & 5.40 & 6.50 & 0.00 & 0.00 & 0.00 & 0.27 & 22.92 & 402.81 & 7.35 \\
\hline Micropogonias furnieri & 55.44 & 13.80 & 76.62 & 10.22 & 125.51 & 9.08 & 223.67 & 3.15 & 238.83 & 13.35 & 229.86 & 0.53 \\
\hline Cynoscion jamaicensis & 54.61 & 14.56 & 82.58 & 14.88 & 83.55 & 5.70 & 115.58 & 7.49 & 52.98 & 33.52 & 89.59 & 3.87 \\
\hline Menticirrhus spp & 62.30 & 6.71 & 55.96 & 14.49 & 43.59 & 9.14 & 60.07 & 8.95 & 32.55 & 22.20 & 33.97 & 0.54 \\
\hline Anchoviella lepidentostole & 78.68 & 9.26 & 150.63 & 15.43 & 10.05 & 21.42 & 1.98 & 37.04 & 0.77 & 55.12 & 0.83 & 53.43 \\
\hline Macrodon atricauda & 52.08 & 10.41 & 60.54 & 1.06 & 30.68 & 0.65 & 44.23 & 0.31 & 56.30 & 0.29 & 51.61 & 4.82 \\
\hline Selene spp & 6.65 & 7.14 & 3.95 & 34.19 & 109.37 & 0.18 & 54.46 & 30.08 & 15.03 & 8.59 & 27.18 & 0.07 \\
\hline Ariidae & 11.80 & 2.90 & 16.97 & 12.99 & 10.33 & 17.08 & 23.27 & 13.80 & 21.44 & 19.12 & 23.96 & 25.05 \\
\hline Prionotus spp & 13.15 & 4.81 & 13.45 & 25.76 & 10.97 & 18.56 & 16.69 & 25.94 & 9.07 & 23.36 & 36.07 & 6.55 \\
\hline Crassostrea brasiliana & 0.81 & 6.20 & 6.95 & 36.34 & 35.55 & 27.12 & 37.09 & 35.17 & 40.09 & 34.16 & 33.91 & 47.36 \\
\hline Opisthonema oglinum & 0.03 & 4.53 & 0.02 & 0.00 & 0.03 & 10.14 & 61.42 & 0.05 & 195.15 & 0.01 & 26.70 & 0.00 \\
\hline Octopus vulgaris & 10.58 & 2.58 & 24.79 & 0.52 & 32.49 & 0.19 & 23.86 & 0.01 & 20.91 & 0.00 & 27.07 & 8.96 \\
\hline Oligoplites spp & 54.71 & 2.57 & 28.11 & 1.09 & 11.54 & 8.38 & 19.70 & 3.18 & 14.48 & 11.06 & 13.03 & 11.52 \\
\hline Trichiurus lepturus & 34.91 & 6.17 & 29.89 & 24.79 & 17.51 & 14.33 & 34.22 & 5.57 & 23.17 & 17.60 & 18.33 & 5.04 \\
\hline Mugil liza & 12.27 & 20.62 & 5.43 & 19.59 & 6.06 & 16.77 & 7.98 & 17.94 & 12.51 & 15.32 & 43.95 & 19.35 \\
\hline Farfantepenaeus spp & 4.05 & 2.35 & 8.80 & 12.21 & 2.36 & 0.00 & 0.00 & 0.00 & 0.00 & 0.00 & 25.35 & 8.47 \\
\hline Urophycis spp & 18.58 & 16.48 & 25.84 & 11.85 & 29.03 & 30.73 & 1.62 & 0.00 & 0.83 & 58.74 & 4.10 & 17.94 \\
\hline Doryteuthis spp & 44.59 & 15.94 & 24.67 & 2.95 & 30.12 & 1.65 & 44.26 & 3.93 & 18.99 & 3.81 & 6.90 & 10.20 \\
\hline Caranx crysos & 11.08 & 1.85 & 111.94 & 6.62 & 16.75 & 18.68 & 3.89 & 19.91 & 2.66 & 3.77 & 2.63 & 23.33 \\
\hline Landed incidental catch * & 55.64 & 5.46 & 68.11 & 8.49 & 50.79 & 7.09 & 56.88 & 6.82 & 51.09 & 3.09 & 96.29 & 3.27 \\
\hline Others & 323.91 & 5.88 & 320.68 & 8.40 & 229.68 & 8.24 & 0.00 & 5.42 & 208.66 & 6.50 & 196.36 & 3.88 \\
\hline Total & 1170.96 & 2.99 & 1355.35 & 5.69 & 1279.73 & 2.91 & 1390.45 & 2.53 & 1265.60 & 4.25 & 1498.77 & 1.88 \\
\hline \multirow[t]{2}{*}{ Minor taxonomic rank } & \multicolumn{2}{|c|}{ July } & \multicolumn{2}{|c|}{ August } & \multicolumn{2}{|c|}{ September } & \multicolumn{2}{|c|}{ October } & \multicolumn{2}{|c|}{ November } & \multicolumn{2}{|c|}{ December } \\
\hline & $\begin{array}{c}\text { Est. } \\
\text { Catch }\end{array}$ & $\mathrm{CV}$ & $\begin{array}{c}\text { Est. } \\
\text { Catch }\end{array}$ & $C V$ & $\begin{array}{c}\text { Est. } \\
\text { Catch }\end{array}$ & $C V$ & $\begin{array}{c}\text { Est. } \\
\text { Catch }\end{array}$ & $C V$ & $\begin{array}{c}\text { Est. } \\
\text { Catch }\end{array}$ & $C V$ & $\begin{array}{c}\text { Est. } \\
\text { Catch }\end{array}$ & $C V$ \\
\hline Sardinella brasilienses & 0.00 & 0.00 & 895.04 & 5.47 & 469.43 & 0.00 & 1523.79 & 3.70 & 129.09 & 0.03 & 0.93 & 92.58 \\
\hline Xiphopenaeus kroyeri & 275.47 & 7.21 & 186.48 & 5.30 & 266.11 & 6.78 & 285.82 & 6.50 & 273.84 & 8.09 & 234.66 & 9.63 \\
\hline Micropogonias furnieri & 179.24 & 2.05 & 268.33 & 15.97 & 262.83 & 1.78 & 267.38 & 15.35 & 130.22 & 5.89 & 125.99 & 1.87 \\
\hline Cynoscion jamaicensis & 51.15 & 1.86 & 94.59 & 14.65 & 91.42 & 13.45 & 141.65 & 3.67 & 82.67 & 11.79 & 120.02 & 3.25 \\
\hline Menticirrhus spp & 39.50 & 8.84 & 39.74 & 6.54 & 54.11 & 3.47 & 106.30 & 6.89 & 79.79 & 4.35 & 66.88 & 5.82 \\
\hline Anchoviella lepidentostole & 0.63 & 48.14 & 0.71 & 66.99 & 9.00 & 30.51 & 137.08 & 9.58 & 169.89 & 9.40 & 108.75 & 15.63 \\
\hline Macrodon atricauda & 56.44 & 3.50 & 54.54 & 2.79 & 31.00 & 12.17 & 81.91 & 2.78 & 50.06 & 3.67 & 64.83 & 4.59 \\
\hline Selene spp & 29.53 & 0.65 & 3.39 & 10.40 & 81.28 & 0.11 & 144.51 & 1.20 & 4.56 & 23.91 & 2.47 & 1.31 \\
\hline Ariidae & 17.84 & 14.87 & 28.18 & 34.41 & 21.12 & 20.75 & 58.93 & 15.35 & 118.10 & 25.57 & 123.70 & 29.89 \\
\hline Prionotus spp & 58.58 & 17.88 & 51.71 & 2.76 & 41.48 & 4.38 & 54.38 & 13.54 & 39.51 & 22.01 & 30.23 & 9.26 \\
\hline Crassostrea brasiliana & 39.72 & 37.43 & 44.16 & 36.62 & 37.05 & 35.77 & 41.40 & 32.24 & 29.72 & 39.59 & 9.37 & 76.70 \\
\hline Opisthonema oglinum & 29.95 & 0.18 & 21.44 & 3.22 & 2.01 & 15.58 & 4.30 & 22.39 & 0.92 & 0.35 & 0.82 & 1.48 \\
\hline Octopus vulgaris & 18.21 & 4.46 & 27.13 & 0.16 & 48.22 & 7.64 & 30.85 & 10.40 & 21.52 & 10.24 & 31.06 & 6.73 \\
\hline Oligoplites spp & 13.96 & 14.47 & 10.17 & 12.75 & 5.15 & 19.62 & 5.23 & 18.89 & 19.84 & 9.85 & 89.15 & 1.27 \\
\hline Trichiurus lepturus & 16.78 & 7.78 & 16.71 & 13.56 & 11.94 & 10.25 & 28.17 & 25.25 & 17.60 & 13.49 & 21.87 & 3.28 \\
\hline
\end{tabular}




\begin{tabular}{lcccccccccccc}
\hline Mugil liza & 58.11 & 10.33 & 22.47 & 15.66 & 44.02 & 31.75 & 13.37 & 23.07 & 7.67 & 24.29 & 4.11 & 9.97 \\
Farfantepenaeus spp & 44.73 & 28.22 & 24.23 & 11.62 & 22.68 & 14.17 & 43.36 & 18.14 & 28.56 & 21.45 & 23.20 & 12.72 \\
Urophycis spp & 14.74 & 27.13 & 35.30 & 1.72 & 14.24 & 0.00 & 9.78 & 43.97 & 24.68 & 18.83 & 38.29 & 26.22 \\
Doryteuthis spp & 2.75 & 43.82 & 0.80 & 0.00 & 0.95 & 3.63 & 2.82 & 73.75 & 10.64 & 14.06 & 20.61 & 14.57 \\
Caranx crysos & 0.59 & 12.06 & 0.61 & 28.57 & 0.70 & 26.02 & 0.50 & 39.86 & 2.95 & 31.93 & 3.76 & 13.57 \\
Landed incidental catch * & 73.71 & 18.75 & 73.42 & 8.50 & 65.90 & 12.80 & 105.94 & 12.40 & 39.16 & 4.20 & 97.68 & 8.50 \\
Others & 264.66 & 9.40 & 295.84 & 3.06 & 229.62 & 4.58 & 291.73 & 6.47 & 298.05 & 9.69 & 323.69 & 7.01 \\
\hline Total & 1286.30 & 3.86 & 2194.97 & 2.18 & 1810.24 & 1.88 & 3379.20 & 1.74 & 1579.03 & 5.00 & 1542.09 & 3.43
\end{tabular}

* Fish of small size and/or low or no commercial value, however landed and marketed, composing the category called "Mistura" in fisheries statistics of the São Paulo State.

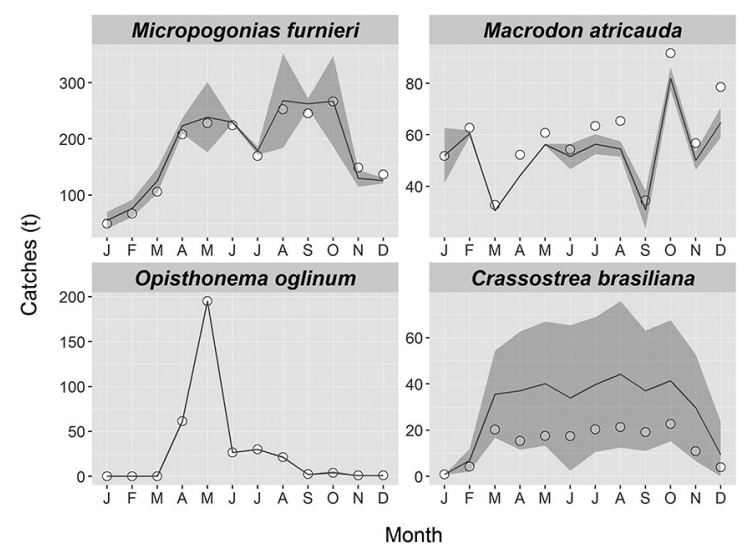

Figure 3. True total landed catches of 2011 (open circle), estimated total landed catches (line), both in tons, and confidence interval of $95 \%$ (shaded area) by month to four of the 20 main species landed over 2011 on the São Paulo coast.

of the São Paulo coast with sampling design compared to the census (10.9\% in SP1 and $13.8 \%$ in SP2).

The more detail is needed and the more variables are involved, the less accurate the estimates become. According to BOLFARINE and BUSSAB (2005), accurate estimates result from considering them explicitly when developing the sampling design, as it is the case herein for the estimated total catch by municipality. Although the variable month has not been considered in the sampling design, estimated monthly total catch for São Paulo State was also a good result since there was sufficient information by month in the sample. In contrast, after breaking down these data by fish category, a much lower accuracy was obtained, particularly for some fish categories such as $C$. brasiliana, M. Lisa, Farfantepenaeus spp and Doryteuthis spp, all of them economically important for the São Paulo State. Detailing data even further, by fishing gear or fleet type, would only make matters worse.

However, the landed catch per landing (LPUE) turned out to be a robust estimate, for most but a very few fish categories. This was facilitated because all landings of the sampled ports were considered. Furthermore, when both the catch and the number of trips are simultaneously under- or overestimated, this bias tends to be canceled out. However, since this estimated LPUE was based on a sampling plan designed specifically for the São Paulo State, its performance with the consolidated fishery data from other States with different sample designs must be further investigated. The assessment and interpretation of a temporal series of the estimated LPUE may also be a problem, mainly for species with little information in the sample or with less precise estimates, when sample errors are greater than the variations of the LPUE itself.

The results obtained for four fish categories have been selected to illustrate distinct situations that can also occur in other survey samplings for fisheries monitoring. First of them is the Opisthonema oglinum, which had very precise and unbiased estimates since the vast majority of the landings and of the landed catch occurred in ports that had been allocated into the census strata. The second situation is described by the estimated monthly catch of M. furnieri, which was unbiased but less precise. Many landings covering a wide range of landed catches of this species occurred in most of the sampled ports, which truly represents the situation in the ports of São Paulo. The third situation is described by M. atricauda, for which the sampled ports recorded fewer landings and lower catches in comparison to what really happens in all ports. Thus, moderately imprecise and underestimated landed catches were obtained. Finally, C. brasiliana represents the worst that can happen during a sampling process and shows the importance of having good knowledge about the ports before the stratification is defined. An enormous variation in landed catch of this species was recorded based on sampled ports while a very specific port, which almost exclusively has landings of this resource, was also part of the sample. This port had been wrongly allocated into a sampled stratum rather than into the census stratum as it should, causing distortion and overestimation of the landed catch after being expanded over the sampled stratum. 
In general, information gathered from well-designed survey samples may have some advantages compared to a complete data collection (census). According to COCHRAN (1977), accurate and reliable estimates can be produced at a much lower cost and data can be obtained and consolidated more quickly applying sampling methods. In addition, survey samplings may have more scope and suppleness regarding the type and amount of information that can be obtained, since only a part of the population is being considered (FAO, 1999). However, these announced advantages were not clearly observed by the sampling design that was applied to monitor the fisheries on the São Paulo coast.

Some issues that may cause concern will be mentioned next. The high-diversified fishing activity affected the accuracy in the estimated catch by fish category. The cost reduction obtained with the sampling was minor and may not compensate the loss of quality of the fishing information compared to the census data. Fishing vessels and fishermen who are not included in the sample cannot be supplied with a proof of activity and of fisheries production, documents required to obtain benefits such as bank loans and fishing licenses. The true fishing area covered by the fleet in operation might be underestimated, since vessels distribution is underrepresented. Finally, the lack of fishing effort measurements that are more appropriate for each fishing fleet makes the fish stock assessment difficult.

The choice of a fishing data collection methodology depends very much on the goals of fisheries monitoring (FAO, 1999). In this study, it was clear that a survey sampling for fisheries monitoring is very useful when financial resources are limited and there is the interest only in a broad picture, without details about the catches. It is understood that it is possible to have more detailed and reliable fishing data increasing the complexity of the sampling design and the costs of the fishing monitoring as well. Or even, to begin with a simple sampling design and, as far as it is feasible, gradually expand to a census methodology (FAO, 1999). In this case, low cost strategies, such as self-registration and mobile field agents, may be adopted. Both strategies have been adopted since the beginning of the Fishing Activity Monitoring Program (PMAP) of the São Paulo coast. However, regardless of the methodology and whatever the cost of a fisheries monitoring program might be, one thing is for sure, it will always be lower than the economic, social and environmental costs of not having quality data to perform evidence based fisheries management.

\section{ACKNOWLEDGEMENTS}

This work is part of the doctoral degree in Biological Oceanography of the first author working under the supervision of the second. We express our thanks to the fisheries scientists and technical team of the Fishing Activity Monitoring Program (PMAP) and to the Fisheries Institute of the Department of Agriculture and Food Supply of São Paulo State. We are also thankful to MSc Aristides Pereira Lima Green (IBGE) for all his contribution.

\section{REFERENCES}

ARAgÃO, J. A. N.; MARTins, S. Censo Estrutural da Pesca, Coleta de Dados e Estimação de Desembarques de Pescado. Brasília: IBAMA, 2006. 180 p.

ÁVILA-DA-SILVA, A. O.; CARNEIRO, M. H.; FAGUNDES, L. Sistema gerenciador de banco de dados de controle estatístico de produção pesqueira marinha - ProPesq. In: Anais do XI Congresso Brasileiro de Engenharia de Pesca e I Congresso Latinoamericano de Engenharia de Pesca. Recife, 1999. p. 824-832.

ÁVILA-DA-SILVA, A. O.; CARNEIRO, M. H.; MENDONÇA, J. T.; BASTOS, G. C. C.; MIRANDA, L. V.; RIBEIRO, W. R.; SANTOS, S. Produção Pesqueira Marinha e Estuarina do Estado de São Paulo - Dezembro de 2014. Inf. Pesq. São Paulo, v. 54, p. 1-4, 2015.

BOLFARINE, H.; BUSSAB, W.O. Elementos de Amostragem. 1.ed. São Paulo: Edgar Blücher, 2005. 274 p.

BUSSAB, W. O.; MORETTIN, P. A. Estatística Básica. 7.ed. São Paulo: Saraiva, 2012. 540 p.

CADDY, J. F.; BAZIGOS, J. P. Practical guidelines for statistical monitoring of fisheries in manpower limited situations. FAO Fisheries Technical Paper. $\mathrm{n}^{\circ}$. 257. Rome: FAO, 1985. 86 p.

CADIMA, E. L. Fish stock assessment manual. FAO Fisheries Technical Paper. $n^{\circ}$. 393. Rome: FAO, 2003. 161 p.

CADIMA, E. L.; CARAMELO, A. M.; AFONSO-DIAS, M.; CONTE DE BARROS, P.; TANDSTAD, M. O.; DE LEIVA-MORENO, J. I. Sampling methods applied to fisheries science: a manual. FAO Fisheries Technical Paper. $n^{\circ} 434$. Rome: FAO, 2005. 88 p.

COCHRAN, W. G. Sampling Techniques. New York: John Wiley \& Sons, 1977. $428 \mathrm{p}$.

DIAS-NETO, J. Pesca no Brasil e seus aspectos institucionais um registro para o futuro. Rev. CEPSUL - Biodivers. Conserv. Mar., v. 1, n. 1, p. 66-80, 2010.

DIAS-NETO, J. Números e Baionetas - A Nova Estatística da Produção Pesqueira do Brasil. Erro Estatístico ou Equívoco Político? Pesca \& Mar - Informativo SAPERJ (março/abril). Rio de Janeiro/RJ. v. 132, p. 31-34, 2011.

FAO. Guidelines for the routine collection of capture fishery data. FAO Fisheries Technical Paper. $n^{\circ}$ 382. Rome: FAO, 1999. $113 \mathrm{p}$. 
HILBORN, R.; WALTERS, C. J. Quantitative fisheries stock assessment: choice, dynamics and uncertainty. New York: Chapman and Hall, 1992. 570 p.

HORVITZ, D. G.; THOMPSON, D. J. A generalization of sampling without replacement from a finite universe. J. Am. Stat. Assoc., v. 47, n. 260, p. 663-685, 1952.

ISSAC, V. J.; RUFFINO, M. L.; MELLO, P. Considerações sobre o Método de Amostragem para a Coleta de Dados sobre Captura e Esforço Pesqueiro no Médio Amazonas. In: IBAMA. (Org.). Recursos Pesqueiros do Médio Amazonas: Biologia e Estatística Pesqueira. Brasília: Edições IBAMA, 2000. p. 175-199.

ISSAC, V. J.; ESPÍRITO SANTO, R. V.; NUNES, J. L. G. A estatística pesqueira no litoral do Pará: resultados divergentes. Pan-Am. J. Aquat. Sci., v. 3, n. 3, p. 205-213, 2008.

LIMA-GREEN, A. P.; MOREIRA, G. G. Metodologia Estatística da Pesca: pesca embarcada. Textos para Discussão. Diretoria de Pesquisas. Rio de Janeiro: IBGE, 2012. p. 1-52.
LUMLEY, T. Complex surveys: a guide to analysis using R. Hoboken: John Wiley \& Sons, 2010. 276 p.

LUMLEY, T. Survey: analysis of complex survey samples. R package version 3.30. 2014.

MENDONÇA, J. T.; MIRANDA, L. V. Estatística pesqueira do litoral sul do estado de São Paulo: subsídios para gestão compartilhada. Pan-Am. J. Aquat. Sci., v. 3, n. 3, p. 152-173, 2008.

R CORE TEAM R. A language and environment for statistical computing. R Foundation for Statistical Computing. Vienna, Austria. 2015. Disponível em: <http://www.R-project.org>. Acesso em: 10 dez. 2015

TILLÉ, Y.; MATEI, A. Sampling: Survey Sampling. R package version 2.7. 2015. Disponível em: $<$ http://CRAN.R-project. org/package $=$ sampling $>$. Acesso em: 10 dez. 2015. 